\title{
Rehabilitation of Artificial Degraded Playa Using Palm Mat Water Conservation Techniques
}

\author{
Modi Ahmed and Ali Al-Dousari \\ Environmental and Life Sciences Research Center, Kuwait Institute for Scientific Research, P.O. Box 24885, Safat 13013, Kuwait
}

\begin{abstract}
Kuwait, one of the gulf council member countries, situated in the Northeastern part of the Arabian Peninsula, experiences hyper-arid desert environmental condition due to the geographical location. Kuwait faces many challenges in the sustainable development of the agricultural sector due to the scarcity of arable land, water resources and high rate of land degradation. So it is essential to emphasis the efficient use of the available water and soil resources in a sustainable manner and also to rehabilitate the degraded land using proper rehabilitation techniques. This study concentrates on the water harvesting and organic mulching (e.g., using date palms) methods. The study area is an artificial playa $\left(2,500 \mathrm{~m}^{2}\right)$, formed through the dumping of the gravel quarries in December 2003. The application of the water harvesting and mulching technique in the study showed an improvement of soil physical properties. The average infiltration capacity has increased from $74 \mathrm{~cm}^{3} / \mathrm{min}$ to $112 \mathrm{~cm}^{3} / \mathrm{min}$. The average difference in volume of infiltrated water was $33.5 \%$. The bulk density and porosity of the control plot was $2 \mathrm{~g} / \mathrm{cm}^{3}$ and $27 \%$, respectively; while that of the treated soil was $1.5 \mathrm{~g} / \mathrm{cm}^{3}$ and $44 \%$, respectively. The moisture content of the treated soil was increased to $50 \%$, more than control soil at depth 40-60 cm, and also there was a significant increase in organic matter. The temperature of the treated soil was $2{ }^{\circ} \mathrm{C}$ lower than the control soil at a depth of $60 \mathrm{~cm}$. This study conserved the irrigation water through reducing the proportion of soil evaporation and thus creating an optimum condition for the plant growth.
\end{abstract}

Key words: Desert, hyper-arid, rehabilitation, mulching water, harvesting.

\section{Introduction}

The State of Kuwait covers $17,818 \mathrm{~km}^{2}$ areas, of which $85 \%$ is covered by terrestrial environment. Among 19 different types of land uses identified, the rangeland constitutes about $75 \%$. A vegetation map of Kuwait was published by Omar et al. [1]. Kuwait is classified as hyper-arid to arid (climate) according to the World Atlas of Desertification [2]. Kuwait is characterized by extremely hot and dry summer and cool winter along with occasional rain. Due to hot temperature, evaporation is very high, ranging from 3 $\mathrm{mm} / \mathrm{d}$ (winter) to $16 \mathrm{~mm} / \mathrm{d}$ in summer. The soils in the North are mainly aridisols (calcids and gypsids) and in the South entisols (sandy soils) [3]. Organic matter is less than $1 \%$ and it is observed in a hard pan of gypsic layer locally known as gatch.

Corresponding author: Modi Ahmed, M.Sc., research field: desert rehabilitation. E-mail: mmahmed@kisr.edu.kw.
In Kuwait, the water scarcity, irregular pattern of rainfall, the mobile sand and the prevalence of strong northwesterly winds significantly influence the stability of the fragile ecosystem. Massive soil losses (750-1,000 $\left.\mathrm{m}^{3} / \mathrm{ha}\right)$ in the West Managish area in July 2008 and severe sand encroachment even in areas protected for decades were consequences of the dry seasons [4]. In addition, the irrational exploitation of natural vegetation and soils has accelerated wind erosion. Owing to these reasons, high rate of land degradation prevails in the terrestrial ecosystem of Kuwait. The land degradation in Kuwait is identified in the form of soil erosion (wind and water), loss of vegetation cover, surface crusting and sealing, soil compaction and soil salinization $[5,6]$.

\section{Study Area and Geological Nature}

The study area is located in Liyah, North of Jahra city (Fig. 1). The study area is an artificial playa $\left(2,500 \mathrm{~m}^{2}\right)$, formed after dumping gravel quarries in 
Kuwait in December 2003. Topsoil of the playa is sandy, calcareous and gypsiferous. The study area has been degraded and lost total vegetation cover, and so leads to the extinction of the reptiles and insects. Such was even observed during spring when there was sufficient flora in the surrounding areas. It has also been observed that the stockpile of seeds at the top soil was eliminated after dumping of the gravel quarries. The area of Liyah is about $199.89 \mathrm{~km}^{2}$, which is equivalent to $1.12 \%$ of total area of Kuwait. The area is almost flat interrupted with group of hills, dry valleys and depressions, where rain water is collected only at short period of time. Therefore, the depression has a crusting surface with coarse sand. One of the most common phenomena in Liyah area is high rocky stretches from the East to West. The area is rich with aeolian and gravel deposits. This is direct cause for the start of gravel extraction activities in early 60s of the last century [7].

\section{Materials and Methods}

The major steps involved in designing the water harvesting system called square micro catchments in a degraded artificial playa (Fig. 2a) are:
(1) Before and after applying harvesting system, the biological (density and type of flora and fauna that existed and morphologic characteristics of planted plant), physical and chemical parameters must be identified;

(2) Collect soil samples (control and treated land);

(3) Plow the surface of the compacted soil from 15 $\mathrm{cm}$ to $25 \mathrm{~cm}$ depths to increase soil porosity and infiltration and reduce external runoff (Fig. 2b);

(4) Create square bunds with an area $5 \mathrm{~m} \times 5 \mathrm{~m}$ and the height is between $30 \mathrm{~cm}$ and $50 \mathrm{~cm}$ (Fig. 2c);

(5) Construct $10 \mathrm{~m}^{2}$ runoff basins in each row. The total area is 2,500 $\mathrm{m}^{2}$ (Fig. 2d);

(6) Cover the soil's surface completely with date palm leaves. (Fig. 2e);

(7) Plant drought-resistant shrubs inside each bund such as Lycium shawii (Fig. 2f). This plant grows well in arid areas, along sandy stones ridges and is dominated in Liyah area;

(8) Monitor the bunds. The regular maintenance of mulching process is needed to repair any damages (Figs. 2g and 2h).

Site information is determined through field examination, soil sampling and their analyses in the laboratory. A total of 100 soil samples were collected

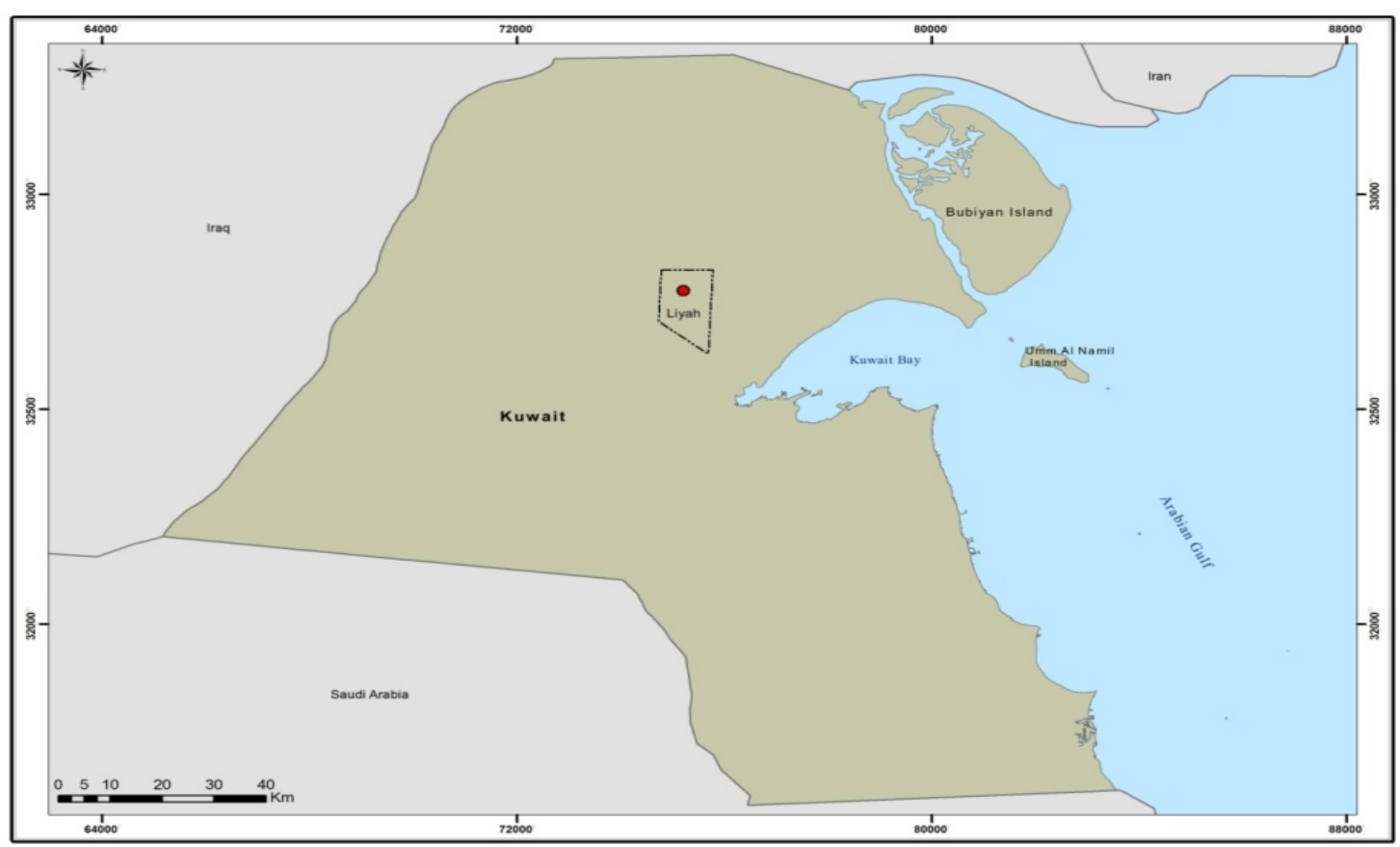

Fig. 1 The location of study area. 


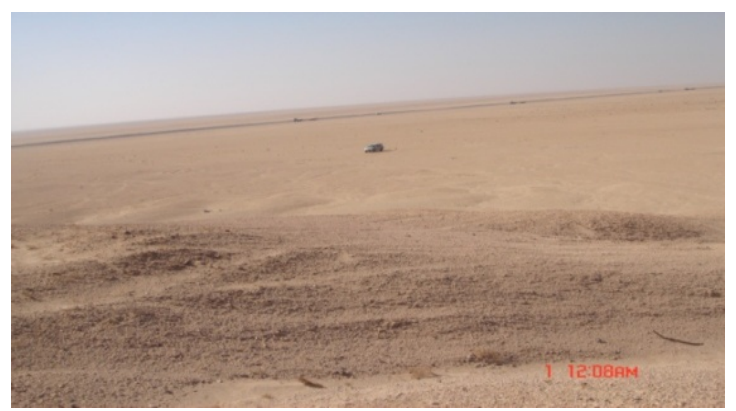

(a) Degraded artificial playa (pilot area)

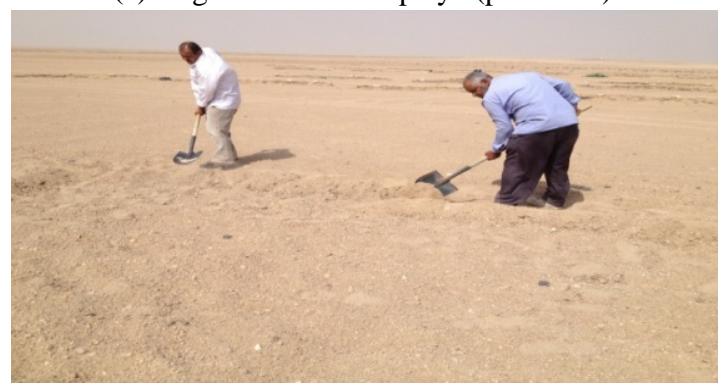

(c) Square bunds of $5 \mathrm{~m} \times 5 \mathrm{~m}\left(25 \mathrm{~m}^{2}\right)$

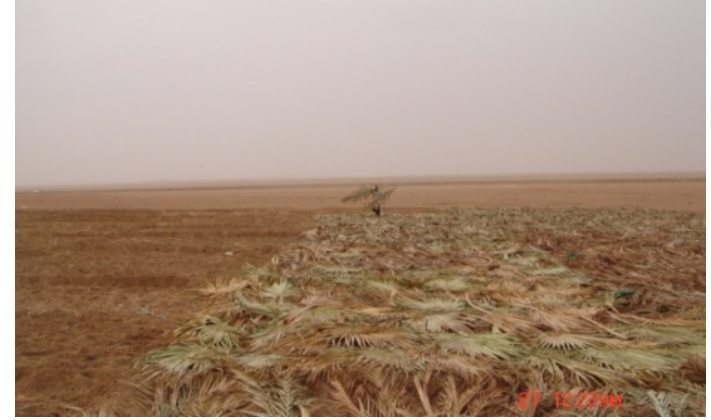

(e) Square bunds covered with date palm leaves (mulching)

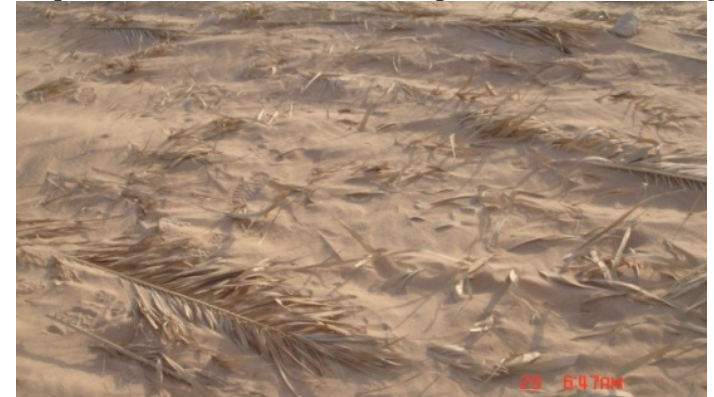

(g) Square bunds and mulching covered with sand

Fig. 2 Preparation of experimental field.

at three depths $(0-20,20-40$ and 40-60 cm). The samples were properly labeled, stored in plastic containers and transferred to the laboratory for analyses.

Field tests: on site investigation includes infiltration rate measurement using standard double ring infiltrometer, bulk density using standard core method

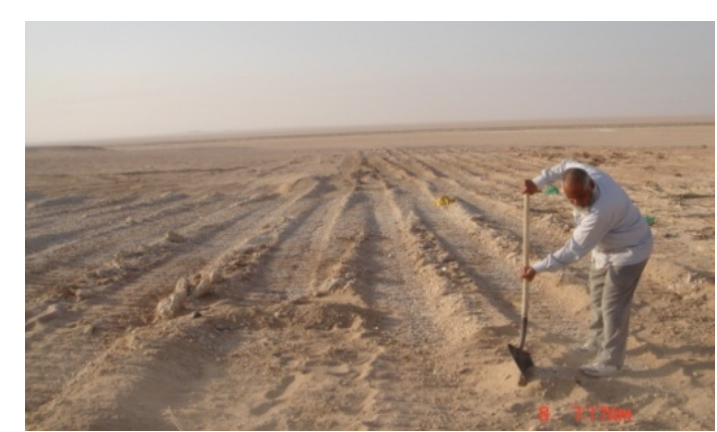

(b) Ploughed compacted soil to a depth of $15 \mathrm{~cm}$ to $25 \mathrm{~cm}$

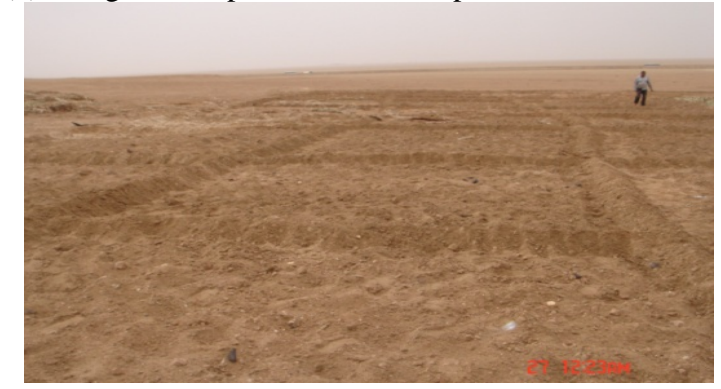

(d) Construction runoff basins

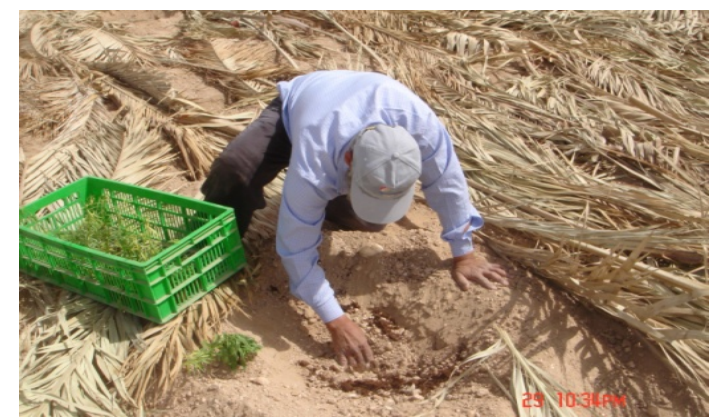

(f) Planting Lycium shawii in each bund

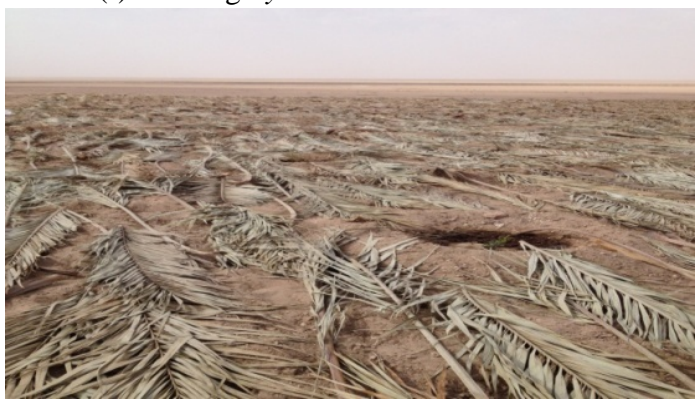

(h) Square bunds covering with new date palm leaves

[8] and calculation of percent pore space using standard formula (porosity $=100(1-b d / p d)$ ), where $b d$ is bulk density and $p d$ is particle density (both are in $\mathrm{g} / \mathrm{cm}^{3}$ ). Soil moisture is determined using gravimetric method through drying the soil at $105^{\circ} \mathrm{C}$ in the oven [8]. The compressive soil strength is measured using hand penetrometer. 
Laboratory tests: particle size distribution was determined by passing the soil material through a set of sieves and the material collected on each sieve was weighed and reported as percentage of the total soil weight [8]. To determine electrical conductivity (EC) and $\mathrm{pH}$ of the soil samples, a portion of soil was used to prepare saturated soil paste. The $\mathrm{pH}$ was then measured on this saturated soil paste using a calibrated $\mathrm{pH}$ meter (an initial two point calibration of $\mathrm{pH} 4$ and $\mathrm{pH} 9$ was performed). After measuring the soil $\mathrm{pH}$, the saturated paste was transferred to the Buckner funnels connected to the vacuum apparatus, and soil saturation extract was collected in collecting vials. The EC of the extract collected from saturated soil paste was determined using EC meter and the values were reported as $\mu \mathrm{S} / \mathrm{cm}$.

\section{Results and Discussion}

To evaluate the differences between the treated (applications of square micro catchments) and control sites, the experiment was conducted for one year, following by measurement of field and laboratory assessments. It has been observed that the average infiltration rate increased from $74 \mathrm{~cm}^{3} / \mathrm{min}$ (control site) to $112 \mathrm{~cm}^{3} / \mathrm{min}$ (treated site). The average difference in volume of infiltrated water was 33.5\% (Table 1; Fig. 3). Such an increase of infiltered water in treated soil is due to the effect of surface ploughing, which improved the soils physical properties and thus resulted the higher infiltration rate relative to control sites (which was not ploughed). No difference in soil moisture content was observed at $20 \mathrm{~cm}$ depth; however, at depths of $40 \mathrm{~cm}$ and $60 \mathrm{~cm}$ soil moisture in treated sites was increased to $50 \%$ over control site (Table 2; Fig. 4). Such an improvement of soil moisture is due to the effect of mulching, which reduced the evaporation and improved water retention and thus soil moisture content. This has ultimately leaded to reducing water requirement of the plants. The addition of mulching material has improved soils physical properties, which resulted to build up soil structure, reduce bulk density from $2 \mathrm{~g} / \mathrm{cm}^{3}$ (control) to $1.5 \mathrm{~g} / \mathrm{cm}^{3}$ (treated soil) and subsequently increase soil porosity from $27 \%$ (control) to $44 \%$ (treated) (Figs. 5 and 6). The improvement of soil porosity presents favorable soil conditions for plant roots to exploit nutrient and

Table 1 Percent difference of infiltrated water at five locations of control and treated sites.

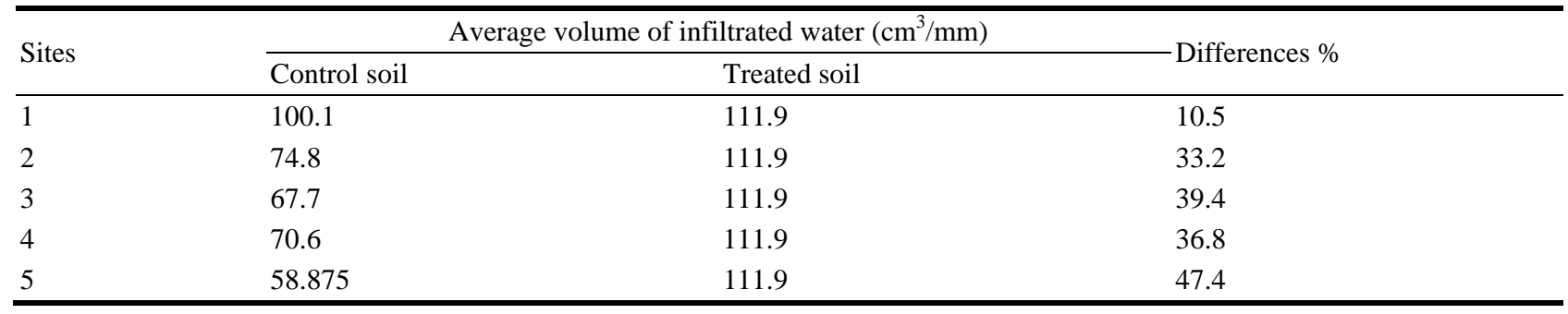

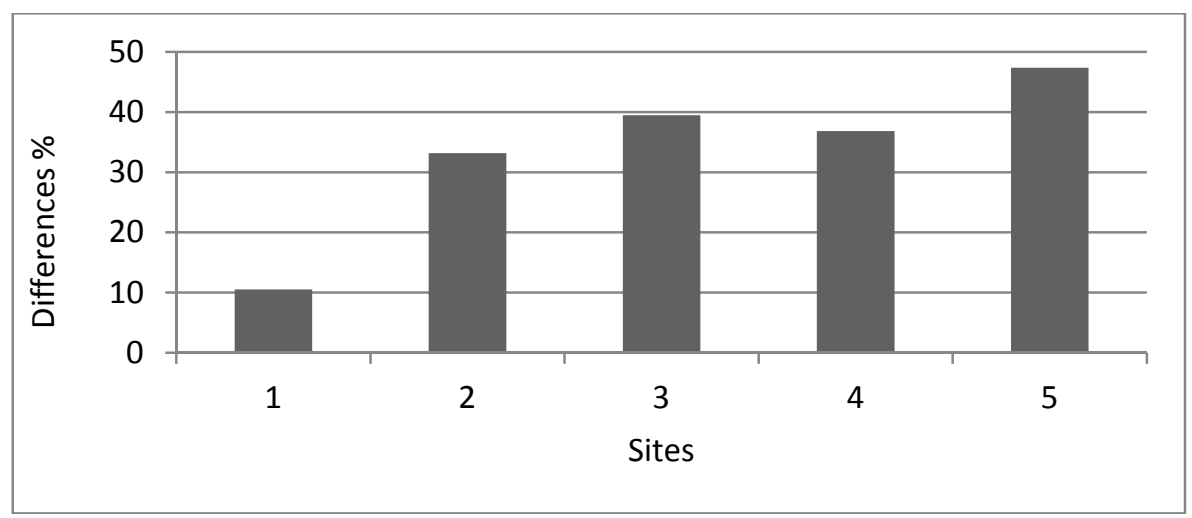

Fig. 3 Percent difference of infiltrated water at five locations of control and treated sites. 
Table 2 In depth percent variation of soil characteristics of treated (T) and control (C) sites.

\begin{tabular}{lllllll}
\hline Sample & Depth $(\mathrm{cm})$ & Moisture content \% & Organic carbon \% & Organic matter \% & $\mathrm{pHs}$ & $\mathrm{EC}(\mu \mathrm{S} / \mathrm{cm})$ \\
\hline C-1 & 0 & 1.00 & 0.32 & 0.56 & 7.14 & 4,040 \\
C-2 & 20 & 4.12 & 0.95 & 1.64 & 7.4 & 5,560 \\
C-3 & 40 & 2.59 & 0.98 & 1.69 & 7.51 & 5,430 \\
C-4 & 60 & 3.17 & 1.13 & 1.95 & 7.5 & 5,120 \\
T-1 & 0 & 0.64 & 0.36 & 0.62 & 7.48 & 4,643 \\
T-2 & 20 & 2.34 & 0.96 & 1.66 & 7.4 & 2,116 \\
T-3 & 40 & 6.32 & 1.27 & 2.19 & 7.49 & 3,010 \\
T-4 & 60 & 5.78 & 1.34 & 2.30 & 7.57 & 3,300 \\
\hline
\end{tabular}

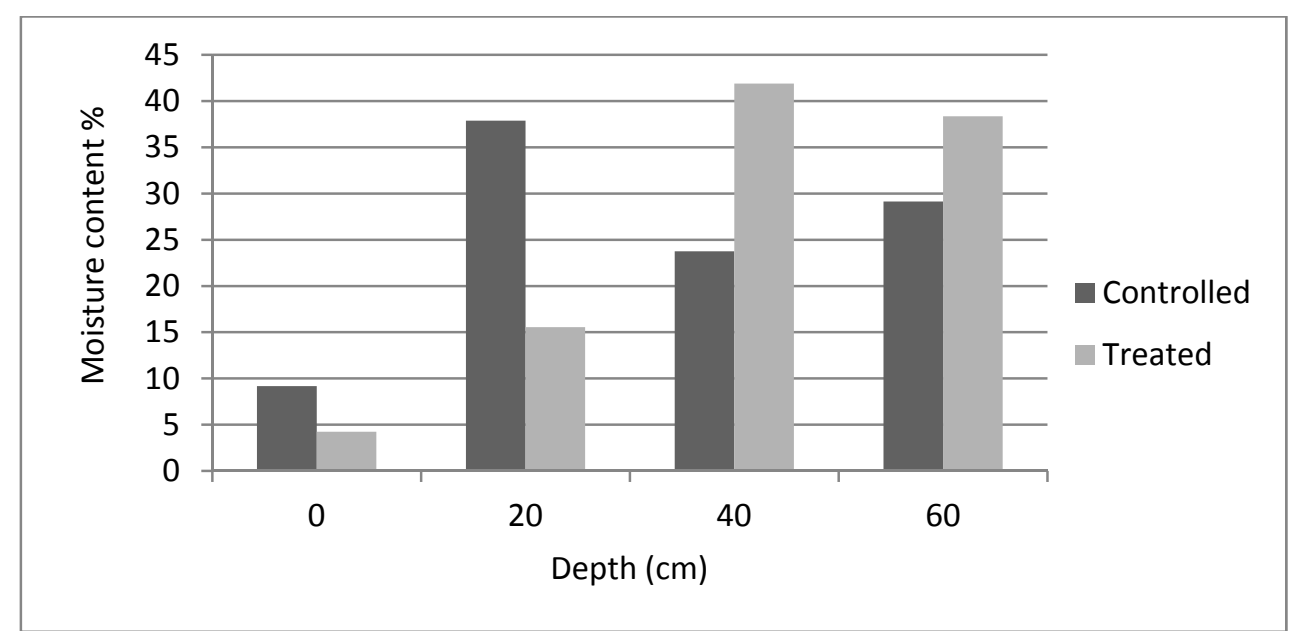

Fig. 4 Variation of soil moisture with depth in the treated and control areas.

moisture from deeper layers compared to control sites. The temperature of the treated soil was lower than control soil. It was reduced to $1-2{ }^{\circ} \mathrm{C}$ (Table 3). It is assumed that the palm mat, acted as insulating material, restricted heat transfer to deeper layers and kept the subsoil relatively cooler to control in summer and warmer in winter. A new layer of soil with an average depth of $26.2 \mathrm{~cm}$ was trapped above the mulched palm leaves with in an area of 2,500 $\mathrm{m}^{2}$. The volume of new trapped layer of soil was $109.2 \mathrm{~m}^{3}$. The trapped sand accumulated above mulching materials is rich in essential elements and organic matter and is consider as seed banks which can play significant role in vegetation regeneration.

At the time of plantation of native Lycium shawii (drought resistant plant), the length of seedlings was 30-40 cm with 2-3 branches (Table 4). We measured the length of the main stem and branches of the plants after one year of plantation. It has been observed that the length of the main stem was between $40 \mathrm{~cm}$ and $100 \mathrm{~cm}$ and the number of branches was 3-8 (Fig. 7a). General health of the plants revealed that mulched plants have better health and vigor. The Lycium shawii preferred to grow in alkaline soil $(\mathrm{pH}$ 7.2-7.9) with low EC. However, these plants have high capability to trap mobile sand through forming large nabkhas [9]. The enhanced quality of soil has led to the appearance of new plant species on the treated soil, such as Fagonia indica, Fagonia bruguieri, Stipagrostis plumosa, Plantago coronopus, Plantago ciliata, plantago boissieri, Rumex vesicarius, Savignya parviflor, Launaea mucronata, Picris babylonica and Diplotaxis harra (Figs. 7b-7e). These plants have created microenvironments for the flora and fauna, where new birds, lizard and insects (ants, bees and beetles) were noticed (Fig. 7f). 


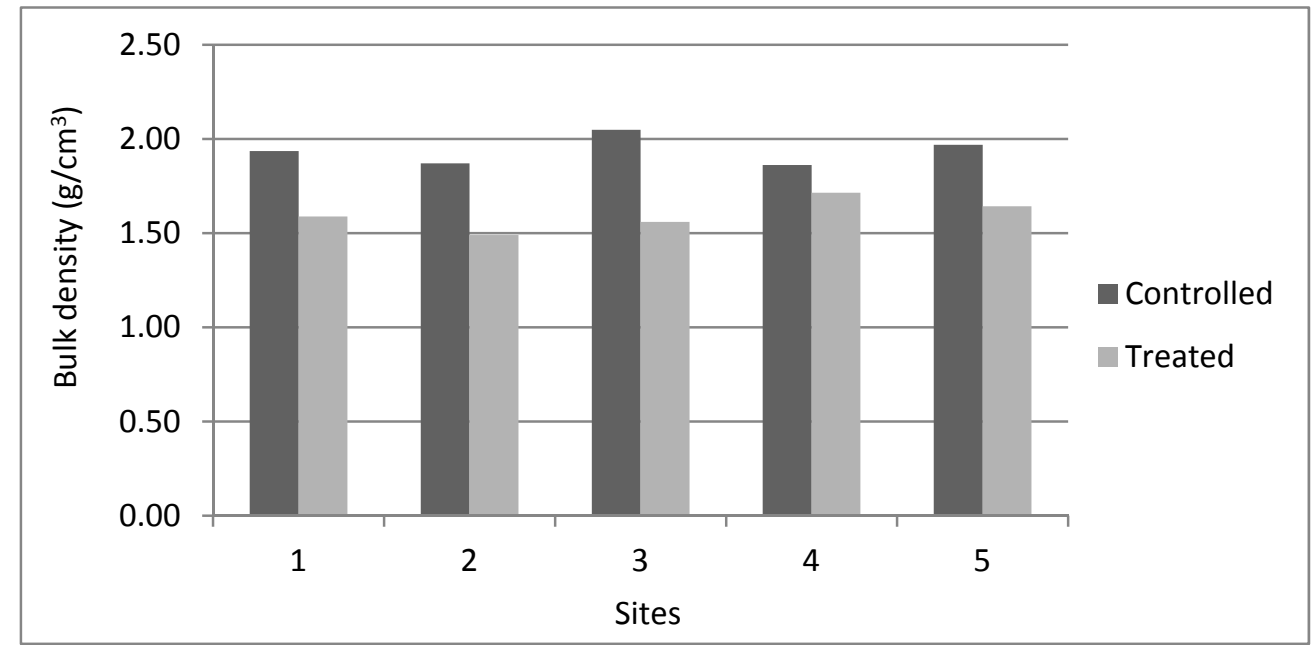

Fig. 5 The variation in the bulk density $\left(\mathrm{g} / \mathrm{cm}^{3}\right)$ in the treated and control sites.

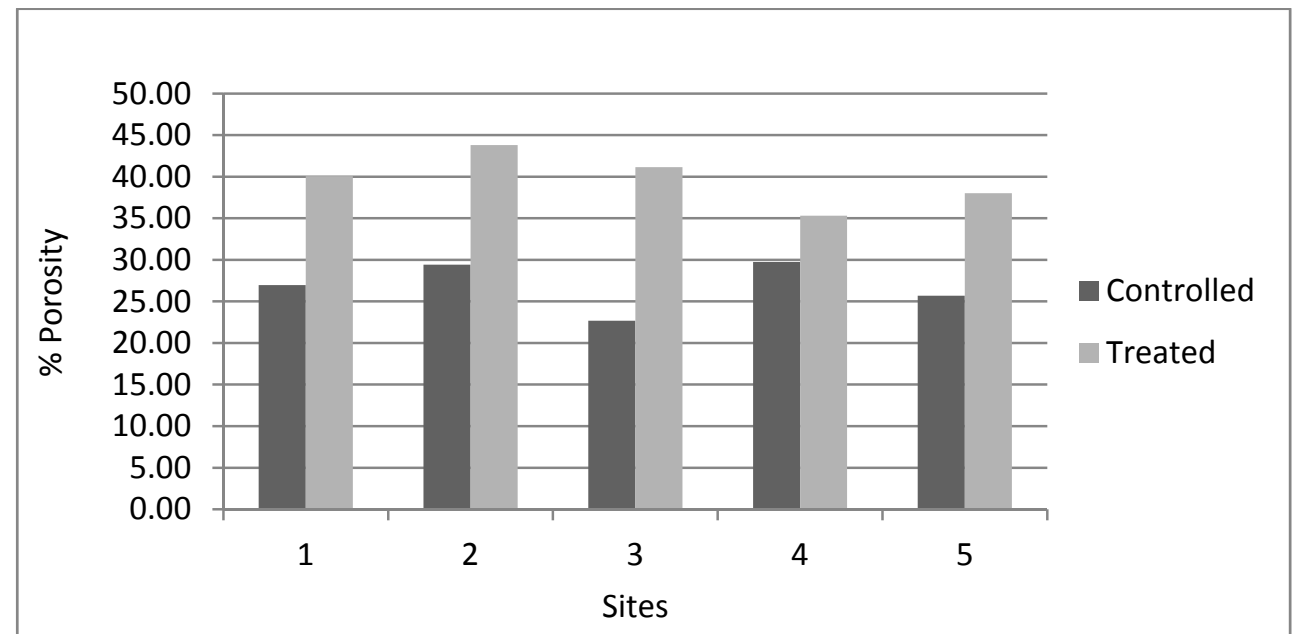

Fig. 6 The variation in soil porosity in the treated and control sites.

Table 3 Soil temperature of control (C) and treated (T) sites at depths of $0,20,40$ and $60 \mathrm{~cm}$.

\begin{tabular}{lllll}
\hline \multirow{2}{*}{ Sample } & \multicolumn{4}{c}{ Temperature $\left({ }^{\circ} \mathrm{C}\right)$} \\
\cline { 2 - 5 } & $0 \mathrm{~cm}$ & $20 \mathrm{~cm}$ & $40 \mathrm{~cm}$ & $60 \mathrm{~cm}$ \\
\hline C-1 & 38.0 & 38.3 & 37.0 & 37.0 \\
C-2 & 40.0 & 40.0 & 39.0 & 38.5 \\
C-3 & 39.5 & 39.0 & 39.0 & 39.0 \\
C-4 & 39.0 & 39.0 & 39.0 & 39.0 \\
T-1 & 36.0 & 35.5 & 35.5 & 35.0 \\
T-2 & 36.0 & 36.0 & 35.5 & 35.5 \\
T-3 & 37.5 & 37.0 & 36.0 & 35.0 \\
T-4 & 36.5 & 36.5 & 36.0 & 36.0 \\
\hline
\end{tabular}

There was rarely noticeable change of organic matter until the depth of $20 \mathrm{~cm}$. However, it has shown an appreciable increase in percentage at $40 \mathrm{~cm}$ and $60 \mathrm{~cm}$ depths (Table 2; Fig. 8). Over time with favorable soil moisture content, the date palm leaves are mineralized and gradually release nutrients in soil that encouraged beneficial organism to reproduce. There was no significant variation in the $\mathrm{pH}$. The soil 


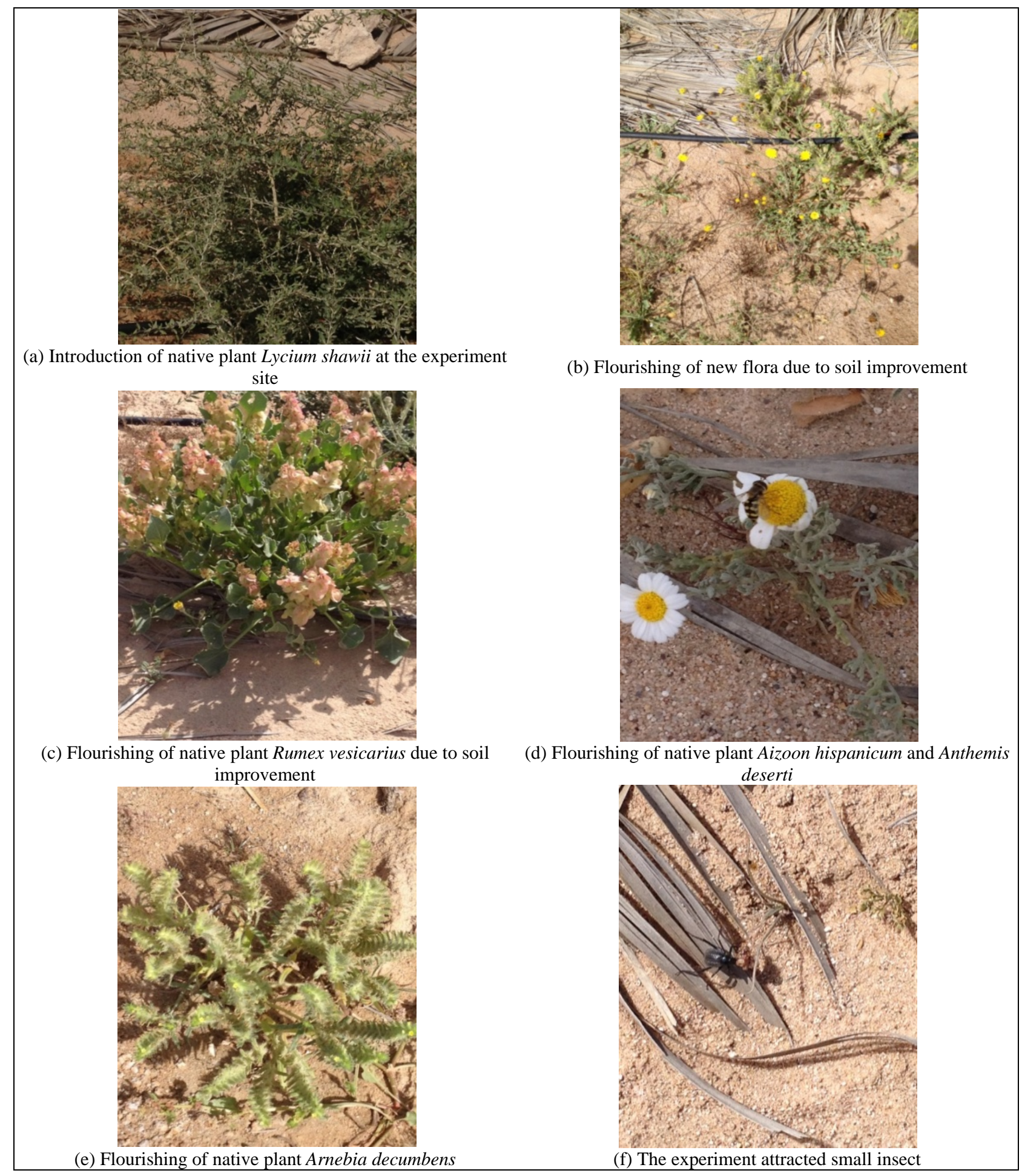

Fig. 7 Some features experimental site.

Table 4 Average physical measurement for Lycium shawii.

\begin{tabular}{lllll}
\hline Treatment & Length of main stem $(\mathrm{cm})$ & No. of branches & Length of large branches $(\mathrm{cm})$ & Length of short branches $(\mathrm{cm})$ \\
\hline At seedling & $30-40$ & $2-3$ & $30-40$ & $10-25$ \\
After one year & $30-100$ & $3-8$ & $23-80$ & $3-25$ \\
\hline
\end{tabular}


in the controlled and treated area is an alkaline with a $\mathrm{pH}$ ranging between 7.4-7.5. There was a considerable decrease in the EC in the treated area. Especially, at depth of $20 \mathrm{~cm}$, the soil showed high variation in EC from 5,500 $\mu \mathrm{S} / \mathrm{cm}$ to $2,000 \mu \mathrm{S} / \mathrm{cm}$ (Table 2; Fig. 9).

It has been clearly found that the use of palm leaves as an organic covers introduced a marked improvement in soil properties and ultimately reflected positively on wild life. The strong point of using the date palm leaves as mulch material is the fact that they are easily available in agricultural farms and the gardens. This type of mulching material is considered as environmentally friendly, i.e., easy to apply, remove and fix in place and supply organic matter to the soil, and it is economical. The cost of stabilization of $1 \mathrm{~m}^{2}$ soil using date palm leaves is calculated as 0.35 Kuwaiti Dinar. This cost is very low compared to ecomat (Malaysian), metal grid and chemical stabilizer (Table 5).

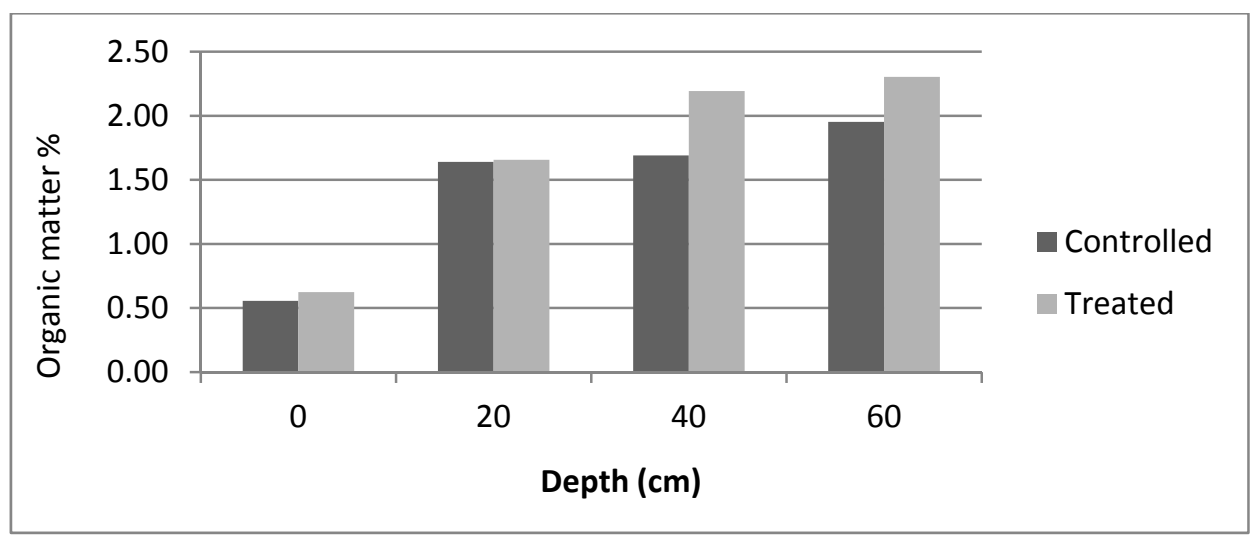

Fig. 8 The variation in the percentage of organic matter with depth in the treated and control areas.

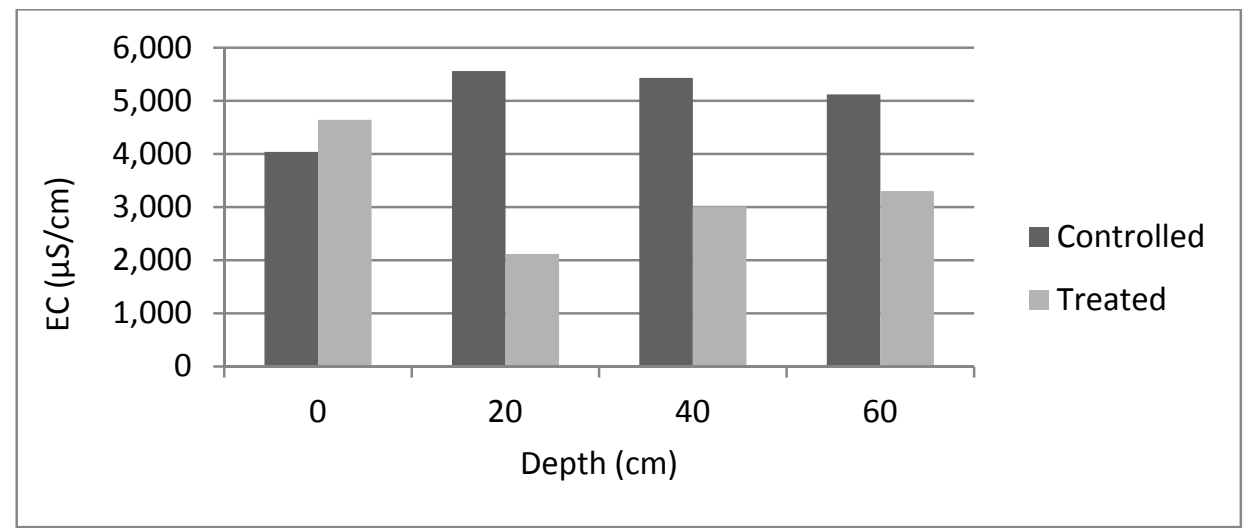

Fig. 9 The variation in the percentage of electrical conductivity (EC) with depth in the treated and control areas.

Table 5 Costs of stabilization of $1 \mathbf{~ m}^{2}$ of soil using different material [10].

\begin{tabular}{lll}
\hline Material & Cost (KWD) & Remarks \\
\hline Local plant residues & $1 \mathrm{KWD}=3.6 \mathrm{USD}$ & Available in agricultural farms and in gardens \\
Chemical (soil stabilizers) & $0.3-0.5^{1}$ & Not recommended \\
Metal grid (checkboard system, 1 m spacing) & $2.4^{4}$ & About $50 \mathrm{~cm}$ high \\
Metal grid (checkboard system, $2 \mathrm{~m}$ spacing) & $1.5^{2}$ & About $50 \mathrm{~cm}$ high \\
Ecomat (Malaysian) & $0.5-0.6^{3}$ & Highly recommended \\
\hline
\end{tabular}

KWD: Kuwaiti Dinar and USD: US Dollar; ${ }^{1}$ value comes from Ref. [11]; ${ }^{2}$ value comes from Ref. [12]; ${ }^{3}$ value comes from Ref. [13]; ${ }^{4}$ source are from local market, 2006. 


\section{Conclusions}

Many attempts have been made in the past under local conditions to enhance soil moisture conservation to sustain the productivity of desert lands. However, it is important to find rehabilitation method using locally available material, which is readily available, economical and eco-friendly. In this regards, we have used date palm leaves to rehabilitate a degraded playa site. During one year experiment, we have concluded: (1) surface plowing of degraded (compacted) soil is essential to improve surface soil properties that ultimately leads to better soil infiltration and moisture conservation; (2) mulching improved water and nutrient retention capacity of the soil, reduced soil erosion, minimized the evaporation rate and created optimum temperature for plant growth and a niche for desert fauna; (3) plantation of square bunds was possible despite the low rainfall; (4) this water harvesting system is very simple in design and economical and easy in implementation; (5) flourishing of new native and drought-resistant plants has improved soil properties at deeper layers; (6) it is important to maintain the site regularly for any damages, especially after wind or rain storm; (7) the cost of bund construction is very low and can be implement rapidly, especially when the raw materials (plant residual) are readily available; (8) the study of playa is important because of their geological features and socio-economic impact; (9) the playa which acts as a catchment area is close to the groundwater level and suitable for agriculture.

\section{References}

[1] Omar, S., Misak, R., Shahid, S. A., Malik, R., Madouh, T., and Abo-Rezq, H. 2001. Rehabilitation and Management of Kuwait's Rangelands for Sustainable Yield. Kuwait Institute for Scientific Research (KISR) Report No. 6087, Kuwait.

[2] Middleton, N., and Thomas, D. S. G. 1997. World Atlas for Desertification, 2nd ed.. London and New York: UNEP/Edward Arnold.

[3] Omar, S. A., and Shahid, S. A. 2013. "Reconnaissance Soil Survey for the State of Kuwait." In Developments in Soil Classification, Land Use Planning and Policy
Implications: Innovative Thinking of Soil Inventory for Land Use Planning and Management of Land Resources, edited by Sahid, S. A., Taha, F. K., and Abdelfattah, M. A. Dordrecht/Heidelberg/New York/London: Springer, 85-107.

[4] Misak, R. F., Khalaf, F. I., and Omar, S. A. S. 2013. "Managing the Hazards of Drought and Shifting Sands in Dry Lands: A Case Study of Kuwait.” In Developments in Soil Classification, Land Use Planning and Policy Implications-Innovative Thinking of Soil Inventory for Land Use Planning and Management of Land Resources, edited by Sahid, S. A., Taha, F. K., and Abdelfattah, M. A. Dordrecht/Heidelberg/New York/London: Springer, 703-29.

[5] Shahid, S. A., Omar, S. A. S., and Al-Ghawas, S. 1999. "Indicators of Desertification in Kuwait and Their Possible Management.” Desertification Control Bulletin 34: 61-6.

[6] Shahid, S. A., Omar, S. A. S., Misak, R. F., and Rizq, H. A. 2003. "Land Resources Stresses and Degradation in the Arid Environment of Kuwait." In Desertification in the Third Millennium, edited by Alsharhan, A. S., Wood, W. W., Goudie, A. S., Flower, A., and Abdellatif, E. M. Lisse, the Netherlands: Swets and Zeitlinger Publishers, 351-60.

[7] Al-Hajraf, S., Al-Enezi, A., Al-Dousari, A. M., Brown, J., and Delima, E. 2008. Environmental Rehabilitation Study of Quarries on the State of Kuwait. Kuwait Institute for Scientific Research (KISR) Final Report No. 9475, Kuwait.

[8] USDA-NRCS. 2004. Soil Survey Laboratory Methods Manual. Soil Survey Investigations Report No. 42, Version 4.0, US Government Printing Office, Washington, DC.

[9] Al-Dousari, A. M., Ahmed, M., Al-Senafy, M., and Al-Mutairi, M. 2008. "Characteristics of Nabkhas in Relation to Dominant Perennial Plant Species in Kuwait.” Kuwait J. of Science and Engineering 35 (1): 129-50.

[10] Misak, R., Al-Dousari, A., and Al-Hagraf, S. 2007. "Combating Land Degradation Using Eco-Friendly Materials.” Presented at International Conference on Desertification Control in the Arid Region, May 12-15, Kuwait Institute for Scientific Research, Kuwait.

[11] Misak, R. F. 2014. “Controlling Land Degradation Using Environmentally Friendly Materials: The Case Study of Kuwait.” J. of Arid Land Studies 24 (1): 73-6.

[12] Ramadan, A. 2008. Assessment of Available Sand Stabilization Techniques at As-Salmi Road: An Experimental Case Study. KISR Final Report.

[13] Arabian Scientific Consultancy Center (ASCC). 2008. Protection of Pipelines against Shifting Sands in West Kuwait (Pilot Site). Technical Report to Kuwait Oil Company (KOC). 